\title{
FINANSOWANIE INWESTYCJI RZECZOWYCH W NIEMIECKIM SEKTORZE PRZEDSIĘBIORSTW
}

\author{
Adam Samborski \\ Katedra Zarządzania Przedsiębiorstwem \\ Uniwersytet Ekonomiczny w Katowicach
}

\begin{abstract}
Abstrakt. W artykule przyjęto dwa cele, a mianowicie: zaadoptowanie sposobu badawczego zaproponowanego przez Corbett i Jenkinson'a do wymogów Europejskiego Systemu Rachunków 2010; identyfikacja struktury finansowania inwestycji rzeczowych w niemieckim sektorze przedsiębiorstw. W analizach wykorzystano dane pochodzące ze sprawozdawczości narodowej, a dokładniej z dwóch rachunków wchodzących w skład rachunków akumulacji, tj.: rachunku kapitałowego oraz rachunku finansowego. Przyjęto metodologię źródeł finansowania netto, w której wykorzystano przepływy środków finansowych, a nie ich stany. Identyfikując strukturę źródeł finansowania inwestycji rzeczowych zauważono, iż w niemieckim sektorze przedsiębiorstw dominują środki wewnętrzne i transfery kapitałowe.
\end{abstract}

Słowa kluczowe: inwestycje rzeczowe, struktura finansowania inwestycji

\section{WSTĘP}

Corbett i Jenkinson [1997] zauważają, iż od dłuższego czasu trwa debata na temat związków pomiędzy finansowaniem a poziomem inwestycji rzeczowych realizowanych przez przedsiębiorstwa. Jednym z wątków tej debaty jest zróżnicowany dostęp do źródeł finansowania w poszczególnych krajach [Corbett, Jenkinson 1997, s. 69]. Ciągle aktualne jest więc pytanie o źródła finansowania inwestycji rzeczowych w sektorze przedsiębiorstw. Pytanie to w drugiej połowie lat 90. postawili m.in. Corbett i Jenkinson [1996, 1997]. Co jednak wyróżnia prace tej dwójki autorów na tle dziesiątek opracowań poruszających podobne kwestie. Odpowiedzi należy upatrywać w sposobie postępowania badawczego. Zaproponowali oni bowiem, aby 
w porównaniach międzynarodowych, dotyczących struktury finansowania inwestycji rzeczowych w sektorze przedsiębiorstw wykorzystywać rachunki narodowe. Rachunki narodowe są bowiem źródłem spójnych danych umożliwiających dokonywanie łatwych i wiarygodnych porównań wybranych wielkości makroekonomicznych. Nie można oczywiście zapominać o publikacjach Mayer [1988, 1990] z końca lat 80., która również wykorzystywała rachunki narodowe w szacowaniu struktury finansowania. Opracowania Corbett i Jenkinson'a, zdaniem Autora, cechuje jednak większa przejrzystość wywodu. Celem artykułu jest więc z jednej strony zaadoptowanie sposobu badawczego zaproponowanego przez Corbett i Jenkinson'a do wymogów Europejskiego Systemy Rachunków 2010, z drugiej identyfikacja struktury finansowania inwestycji rzeczowych w niemieckim sektorze przedsiębiorstw.

\section{KONCEPTUALIZACJA BADAŃ}

W prowadzonych analizach wykorzystane zostaną więc dane pochodzące z rachunków narodowych sporządzonych zgodnie z Europejskim Systemem Rachunków 2010 (ESA 2010). System ten został szczegółowo omówiony w Rozporządzeniu Parlamentu Europejskiego i Rady (UE) NR 549/2013 z dnia 21 maja 2013 r. w sprawie europejskiego systemu rachunków narodowych i regionalnych w Unii Europejskiej. „Europejski System Rachunków [...] stanowi międzynarodowy standard metodologiczny i rachunkowy dla szczegółowego i systematycznego opisu gospodarki ogółem [...], jej składowych oraz relacji z innymi gospodarkami ogółem" [1.01, Rozporządzenie NR 549/2013]. W ramach systemu ESA wyodrębnić można dwa główne zestawy tablic. Pierwszy to rachunki sektorów instytucjonalnych, drugi to kompleks przepływów międzygałęziowych i rachunki według gałęzi [1.06, Rozporządzenie NR 549/2013]. W analizach wykorzystane zostaną rachunki sektorów instytucjonalnych. Rachunki te dostarczają „[...] systemowego opisu różnych etapów procesów gospodarczych" [1.07, Rozporządzenie NR 549/2013]. Spośród sektorów instytucjonalnych przedmiotem analiz uczyniono sektor przedsiębiorstw niefinansowych. Zgodnie z rozporządzeniem NR 549/2013 „sektor przedsiębiorstw niefinansowych [...] obejmuje samodzielne jednostki instytucjonalne posiadające osobowość prawną i będące producentami rynkowymi, których podstawową działalnością jest produkcja wyrobów i usług niefinansowych [...]" [2.45, Rozporządzenie Nr 549/2013]. W ramach rachunków narodowych rejestrowane są zarówno przepływy, jak i stany. Kategorie te ujęte zostały w uporządkowanym zestawie rachunków. Rachunki te opisują cykl ekonomiczny, począwszy od produkcji i tworzenia dochodów, następnie poprzez ich podział i redystrybucję, a kończąc na wykorzystaniu w celu spożycia. W ramach rachunków narodowych rejestruje się również wykorzystanie tego, co pozostało w formie oszczędności. Uwzględnia się w ten sposób akumulację 
aktywów, zarówno o charakterze niefinansowym, jak i finansowym [8.02. Rozporządzenie Nr 549/2013]. W każdym z rachunków ujęte zostały przychody i rozchody, które zbilansowano wprowadzając pozycję bilansującą - zazwyczaj po stronie rozchodów. Pozycja bilansująca zostaje przeniesiona do kolejnego rachunku, stanowiąc pierwszą pozycję, którą rejestruje się po stronie przychodów [8.03. Rozporządzenie Nr 549/2013]. Wyróżnia się trzy kategorie rachunków, a mianowicie rachunki bieżące, akumulacji oraz bilanse [8.04. Rozporządzenie Nr 549/2013]. Dane wykorzystywane w analizach pochodzą z rachunków akumulacji, a dokładniej rachunku kapitałowego i finansowego. Rachunki akumulacji pokazują zmiany aktywów i zobowiązań jednostek, dotyczą więc przepływów. Rachunki te rejestrują różne przyczyny zmian aktywów i zobowiązań jednostek, pozwalają także rejestrować zmiany ich wartości netto, która stanowi różnicę pomiędzy aktywami i zobowiązaniami [8.04, 8.44 Rozporządzenie Nr 549/2013]. W części dotyczącej analiz zwrócono uwagę na zmiany związane z transakcjami, które obejmują aktywa rzeczowe, a także aktywa finansowe i zobowiązania [1.128 Rozporządzenie Nr 549/2013]. Pierwszym z rachunków akumulacji jest rachunek kapitałowy. Rejestruje on nabycie pomniejszone o rozdysponowanie aktywów niefinansowych, które dokonywane jest przez jednostki będące rezydentami. Rachunek ten mierzy również zmianę wartości netto z tytułu oszczędności oraz transferów kapitałowych [8.46 Rozporządzenie $\mathrm{Nr}$ 549/2013]. Innymi słowy, rachunek kapitałowy pokazuje „transfery kapitałowe oraz nabycie pomniejszone o rozdysponowanie niefinansowych aktywów nieprodukowanych" [18.03 Rozporządzenie Nr 549/2013]. Rachunek kapitałowy pozwala określić, w jakim stopniu nabycie aktywów niefinansowych pomniejszone o ich rozdysponowanie sfinansowane było z oszczędności i z transferów kapitałowych. Na rachunku tym ujawniona zostaje albo wartość wierzytelności netto, która odpowiada kwocie dostępnej jednostce lub sektorowi na cele finansowania (bezpośrednio czy pośrednio) innych jednostek czy sektorów, albo wartość zadłużenia netto, która odpowiada kwocie jaką jednostka czy sektor muszą pożyczyć od innych jednostek lub sektorów [8.47 Rozporządzenie Nr 549/2013]. Rachunek finansowy pokazuje „transakcje dotyczące aktywów finansowych i zobowiązań" Rachunek finansowy rejestruje więc zmiany aktywów finansowych i zobowiązań, które składają się na wierzytelności czy zadłużenie netto. Rejestracji tej dokonuje się w podziale na poszczególne rodzaje instrumentów finansowych. Wspomniane wierzytelności czy zadłużenie netto $\mathrm{z}$ rachunku finansowego powinny odpowiadać nadwyżce bądź deficytowi finansowemu z rachunku kapitałowego. Nadwyżka czy deficyt finansowy z rachunku kapitałowego są jego pozycjami bilansującymi, które przeniesione zostały do rachunku finansowego jako pierwsza pozycja ujawniona po stronie zmian zobowiązań i wartości netto. Na rachunku finansowym nie ma pozycji bilansującej [8.50, 18.03 Rozporządzenie Nr 549/2013]. Oznacza to, iż w określonym przedziale czasowym w sektorze 
przedsiębiorstw źródła funduszy, czyli przychody, są równe ich wykorzystaniu, tj. rozchodom. Takie zestawienie przychodów i rozchodów nazwać można rachunkiem przepływu funduszy, który pozwala dla sektora przedsiębiorstw oszacować strukturę finansowania (tabela 1). Pamiętać jednak należy, iż nie wszystkie fundusze pozyskane przez przedsiębiorstwo przeznaczane są na inwestycje rzeczowe. Częściowo dokonywana jest również akumulacja finansowa. Tak więc, aby zidentyfikować źródła finansowania związane z inwestycjami rzeczowymi proponuje się, aby przyrost zobowiązań finansowych pomniejszyć o przyrost należności finansowych (tabela 1). W ten sposób dokonany zostanie pomiar struk-

TABELA 1. Rachunek przypływu funduszy

\begin{tabular}{|l|l|}
\hline \multicolumn{2}{|c|}{ Metoda „spłaty netto” } \\
\hline \multicolumn{1}{|c|}{ Przychody brutto } & \multicolumn{1}{c|}{ Rozchody brutto } \\
\hline 1. Wewnętrzne & 9. Gotówka i depozyty \\
\hline 2. Pożyczki bankowe & 10. Akcje zakupione \\
\hline 3. Akcje wyemitowane & 11. Obligacje zakupione \\
\hline 4. Obligacje wyemitowane & $\begin{array}{l}\text { 12. Pozostałe kwoty do otrzymania/ } \\
\text { /zapłacenia }\end{array}$ \\
\hline 5. Pozostałe kwoty do otrzymania/zapłacenia & 13. Transfery kapitałowe \\
\hline 6. Transfery kapitałowe & 14. Inne \\
\hline 7. Inne & 15. Inwestycje rzeczowe \\
\hline 8. PRZYCHODY OGÓŁEM & 16. ROZCHODY OGÓŁEM \\
\hline \multicolumn{1}{|c|}{ Przychody netto } & Retoda „zbilansowana netto” \\
\hline & \\
\hline Wewnętrzne (1) & INWESTYCJE RZECZOWE (15) \\
\hline Bankowe netto (2-9) & \\
\hline Akcje netto (3-10) & \\
\hline Obligacje netto (4-11) & \\
\hline Kredyty handlowe netto (5-12) & \\
\hline Transfery kapitałowe netto (6-13) & \\
\hline Inne netto (7-14) & \\
\hline PRZYCHODY NETTO (8-9-10-11-12-13-14) & \\
\hline
\end{tabular}

Uwagi: Wewnętrzne = oszczędności netto + amortyzacja środków trwałych; obligacje = papiery wartościowe inne niż akcje; akcje = akcje i inne udziały kapitałowe; inne = rezerwy techniczno-ubezpieczeniowe; inwestycje rzeczowe $=$ akumulacja $=$ nakłady brutto na środki trwałe + nabycie pomniejszone o rozdysponowanie nieprodukowanych aktywów niefinansowych.

Źródło: Samborski, 2011, s. 160; Samborski, 2014, s. 24. 
tury finansowania netto inwestycji rzeczowych, pozwalający na określenie znaczenia różnych źródeł funduszy w finansowaniu inwestycji rzeczowych sektora przedsiębiorstw w określonym przedziale czasu [Samborski 2011, s. 152-160; Samborski 2014, s. 23-24].

Corbett i Jenkinson [1996, 1997] mają oczywiście świadomość, iż takie ujęcie źródeł finansowania jest pewnym uproszczeniem. Nie rozgranicza się tutaj przedsiębiorstw, w których wartość kredytów bankowych, odpowiada wartości depozytów od tych, które nie korzystają ani z kredytów bankowych, ani też nie posiadają depozytów. Korzysta się też z danych zagregowanych co powoduje, iż rola niektórych źródeł finansowania jest zaniżana. I tak np. wracając do wspomnianych kredytów bankowych, niektóre przedsiębiorstwa mogą być depozytariuszami netto, inne kredytobiorcami netto, a dzięki agregacji danych finansowanie bankowe netto wyjdzie zero, pomimo tego, iż w części podmiotów gospodarczych źródła bankowe stanowią istotną rolę w finansowaniu ich działalności. Podobnie, jeżeli przedsiębiorstwo zwiększa finansowanie z kapitału udziałowego, przeznaczając w tym samym czasie środki finansowe na zakup akcji w innych podmiotach gospodarczych, wkład kapitału udziałowego w finansowanie inwestycji rzeczowych może okazać się zerowy, pomimo tego, iż przedsiębiorstwo korzystało w tym czasie z rynku kapitałowego [Corbett, Jenkinson 1997, s. 72-73]. Pamiętać jednak należy, iż na źródła finansowania inwestycji rzeczowych patrzymy poprzez pryzmat całego sektora przedsiębiorstw, a nie pojedynczych podmiotów gospodarczych. Ponadto w porównaniach międzynarodowych taki sposób postępowania badawczego zapewnia porównywalność danych.

Kolejna kwestia, która wymaga wyjaśnienia dotyczy tego, iż Corbett i Jenkinson [1996, 1997] w swoim podejściu bazują na przepływach a nie na stanach. Wywód warto rozpocząć od przybliżenia koncepcji przepływów i stanów. „Przepływy odnoszą się do działań i efektów zdarzeń mających miejsce w ramach danego okresu czasu, podczas gdy stany odnoszą się do sytuacji w określonym momencie czasu" [1.64, Rozporządzenie Nr 549/2013]. „Przepływy odzwierciedlają tworzenie, przekształcanie, wymianę, transfery bądź niszczenie wartości ekonomicznych. Powodują one zmiany wartości aktywów lub zobowiązań jednostek instytucjonalnych" [1.65, Rozporządzenie Nr 549/2013]. „Stany są zasobami aktywów i zobowiązań w określonym momencie czasu". Stany rejestruje się na początku i na końcu okresu księgowego [1.85, Rozporządzenie Nr 549/2013]. Sama koncepcja inwestycji jest koncepcją związaną z przepływami. Stąd też zdaniem Corbett i Jenkinson'a w szacowaniu struktury finansowania właściwszym jest wykorzystywanie przepływów a nie stanów [Corbett, Jenkinson 1996, s. 74].

Można tez zastanawiać się nad tym dlaczego Corbett i Jenkinson [1996, 1997], a wcześniej jeszcze Mayer [1988, 1990], zdecydowali się na wykorzystanie sprawozdawczości narodowej a nie sprawozdawczości przedsiębiorstw w szacowaniu struktury finansowania inwestycji rzeczowych w sektorze przedsiębiorstw. 
Warto w tym miejscu przytoczyć argumentację Mayer [1990] - podstawową zaletą danych pozyskanych z rachunku przepływów jest ich wszechstronność oraz szeroki zakres pokrycia, obejmujący cały sektor przedsiębiorstw. Inaczej jest natomiast w przypadku sprawozdawczości przedsiębiorstw, gdzie sprawozdania są dostępne dla ograniczonej liczby podmiotów, a próba często stanowi niewielką część ogólnej liczby przedsiębiorstw [Mayer 1990, s. 326].

\section{STRUKTURA FINANSOWANIA INWESTYCJI RZECZOWYCH}

W tabeli 2 oszacowano strukturę finansowania inwestycji rzeczowych w niemieckim sektorze przedsiębiorstw. Dane dla poszczególnych lat, przedstawione w przekroju poszczególnych źródeł finansowania, stanowią procent wartości dokonanych w tych latach inwestycji rzeczowych.

TABELA 2. Struktura finansowania inwestycji rzeczowych w niemieckim sektorze przedsiębiorstw w latach 1995-2014 (w p. proc.)

\begin{tabular}{|c|c|c|c|c|c|c|c|}
\hline Lata & Wewnętrzne & $\begin{array}{c}\text { Bankowe } \\
\text { netto }\end{array}$ & $\begin{array}{c}\text { Akcje } \\
\text { netto }\end{array}$ & $\begin{array}{c}\text { Obligacje } \\
\text { netto }\end{array}$ & $\begin{array}{c}\text { Kredyty } \\
\text { handlowe } \\
\text { netto }\end{array}$ & $\begin{array}{c}\text { Transfery } \\
\text { kapitałowe } \\
\text { netto }\end{array}$ & $\begin{array}{c}\text { Inne } \\
\text { netto }\end{array}$ \\
\hline 1995 & 79,2 & $-5,6$ & 7,3 & $-33,2$ & 0,0 & 59,6 & 0,8 \\
\hline 1996 & 86,0 & $-1,2$ & 10,9 & 5,5 & 0,0 & 6,6 & 0,8 \\
\hline 1997 & 82,3 & $-3,0$ & 7,2 & 2,9 & 0,0 & 5,9 & 0,2 \\
\hline 1998 & 80,6 & $-8,2$ & $-2,0$ & $-1,2$ & 0,0 & 6,4 & 0,7 \\
\hline 1999 & 67,2 & 26,7 & $-15,4$ & $-13,7$ & $-15,5$ & 5,4 & 0,7 \\
\hline 2000 & 56,3 & 8,9 & 3,6 & $-11,5$ & 9,4 & 4,7 & 3,5 \\
\hline 2001 & 81,3 & $-1,2$ & 10,5 & $-6,4$ & $-2,0$ & 6,6 & 1,7 \\
\hline 2002 & 96,3 & $-10,2$ & $-18,4$ & 22,1 & $-0,3$ & 7,9 & 2,2 \\
\hline 2003 & 92,8 & $-17,4$ & 6,0 & 28,9 & $-26,8$ & 7,6 & 2,1 \\
\hline 2004 & 108,7 & $-26,3$ & $-2,6$ & 22,5 & $-11,8$ & 6,6 & 1,2 \\
\hline 2005 & 102,1 & $-17,4$ & $-2,1$ & 4,1 & 11,9 & 6,5 & 1,1 \\
\hline 2006 & 98,0 & $-5,5$ & $-28,7$ & $-7,6$ & $-19,3$ & 5,5 & 3,0 \\
\hline 2007 & 96,9 & $-2,3$ & $-1,7$ & 4,4 & $-23,1$ & 4,8 & 0,7 \\
\hline 2008 & 86,8 & 4,9 & 22,3 & 14,0 & $-10,6$ & 4,8 & 0,7 \\
\hline 2009 & 113,2 & $-19,2$ & $-8,2$ & $-4,4$ & $-4,6$ & 7,2 & 3,3 \\
\hline 2010 & 114,6 & $-5,8$ & $-17,2$ & 0,9 & 3,7 & 6,4 & 1,8 \\
\hline 2011 & 106,2 & 4,5 & $-10,0$ & 9,4 & $-2,5$ & 5,8 & 1,7 \\
\hline 2012 & 111,6 & $-4,6$ & $-8,3$ & 10,0 & $-23,7$ & 6,5 & 2,2 \\
\hline 2013 & 116,3 & 3,2 & $-1,4$ & 3,3 & $-44,1$ & 6,0 & 1,1 \\
\hline 2014 & 119,4 & 0,8 & 6,6 & 4,4 & 26,9 & 8,4 & 1,0 \\
\hline
\end{tabular}

Źródło: EUROSTAT, Germany http://ec.europa.eu/eurostat/web/sector-accounts/data/annual-data dostęp: 30.08.2016. 
Na podstawie danych zawartych w tabeli 2 dokonano następujących obserwacji:

- Obserwacja 1: podstawowym źródłem finansowania inwestycji rzeczowych w niemieckim sektorze przedsiębiorstw są środki wewnętrzne. Środki wewnętrzne to suma oszczędności netto i amortyzacji środków trwałych. Środki wewnętrzne to więc nic innego jak oszczędności brutto. W przypadku sektora przedsiębiorstw oszczędności brutto są równe dochodom do dyspozycji w tym sektorze [United Nations 2003, s. 91]. W latach 2004, 2005 oraz 2009-2014 wartość dochodów do dyspozycji przewyższała wartość inwestycji rzeczowych. W konsekwencji w okresie tym odnotowano w sektorze przedsiębiorstw wystąpienie wierzytelności netto. Oznacza to, iż w tym czasie z wypracowanych przez sektor przedsiębiorstw środków finansowych korzystały inne sektory instytucjonalne. W pozostałych latach środki wewnętrzne okazały się niewystarczające do pokrycia realizowanych inwestycji rzeczowych. Nie zawsze jednak sektor przedsiębiorstw był zmuszony pożyczać środki finansowe od innych sektorów. Zadłużenie netto, wystąpiło jedynie w latach 1996-2001, oraz w roku 2008. W pozostałych latach wystarczająco duże okazały się transfery kapitałowe netto. Warto jeszcze w tym miejscu zaznaczyć, iż we wszystkich latach poziom samofinansowania był bardzo wysoki. W efekcie środki zewnętrzne nie odgrywają znaczącej roli w finansowaniu inwestycji rzeczowych w niemieckim sektorze przedsiębiorstw.

- Obserwacja 2: transfery kapitałowe netto stanowią istotne źródło finansowania inwestycji rzeczowych w niemieckim sektorze przedsiębiorstw. Czym jednak są transfery kapitałowe w rozumieniu rachunków narodowych. „Transfery kapitałowe wymagają nabycia lub rozdysponowania aktywa lub aktywów przez przynajmniej jedną stronę transakcji" [4.145, Rozporządzenie $\mathrm{Nr}$ 549/2013]. W badanym okresie poziom finansowania inwestycji rzeczowych z transferów kapitałowych utrzymywał się na zbliżonym poziomie kształtując się w przedziale 4,7\% do 8,4\% (obserwacja ta nie dotyczy roku 1995). Wśród transferów kapitałowych znaczącą rolę odgrywają dotacje na inwestycje przekazywane z sektora instytucji rządowych i samorządowych.

- Obserwacja 3: obligacje są istotnym źródłem finansowania inwestycji rzeczowych w niemieckim sektorze przedsiębiorstw. Przedsiębiorstwa niemieckie były szczególnie aktywne na rynku obligacji w latach 2002-2004, 2008, 2011, 2012. Co ciekawe jedynie w 2008 roku odnotowano wystąpienie w sektorze przedsiębiorstw zadłużenia netto.

- Obserwacja 4: wkład sektora bankowego w finansowanie inwestycji rzeczowych w niemieckim sektorze przedsiębiorstw jest znikomy. Trzeba jednak zauważyć, iż konstatacja ta dotyczy danych zagregowanych. W latach 1995-2014 w sektorze przedsiębiorstw nastąpił bowiem przyrost zobowiązań finansowych. 
- Obserwacja 5: rynek instrumentów udziałowych nie stanowi istotnego źródła finansowania inwestycji rzeczowych w niemieckim sektorze przedsiębiorstw. Również i tu konstatacja ta dotyczy danych zagregowanych. W analizowanym okresie w każdym roku przyrost akcji i innych udziałów kapitałowych był dodatni. Przyrost należności finansowych z tytułu posiadanych akcji i innych udziałów kapitałowych był jednak znacznie większy.

- Obserwacja 6: kredyty handlowe nie odgrywają istotnej roli w finansowaniu inwestycji rzeczowych w niemieckim sektorze przedsiębiorstw. Zaciągnięcie zobowiązań netto z tytułu pozostałych kwot do otrzymania/zapłacenia pomniejszone o nabycie aktywów finansowych netto z tytułu pozostałych kwot do otrzymania/zapłacenia w większości przypadków przyjmowało wartości ujemne.

\section{UWAGI KOŃCOWE}

Jak zauważano we wstępie przed artykułem postawiono dwa cele, a mianowicie:

- zaadoptowanie sposobu badawczego zaproponowanego przez Corbett i Jenkinson’a do wymogów Europejskiego Systemy Rachunków 2010,

- identyfikacja struktury finansowania inwestycji rzeczowych w niemieckim sektorze przedsiębiorstw.

Cele te w opinii autora zostały zrealizowane. Sposób postępowania badawczego zaproponowany przez Corbett i Jenkinson'a jest zgodny z ESA2010 i pozwala na identyfikację struktury finansowania inwestycji rzeczowych w sektorze przedsiębiorstw. Świadczy o tym przykład niemieckiego sektora przedsiębiorstw. Z powyższych analiz wynika, iż podstawowym źródłem finansowania inwestycji rzeczowych w niemieckim sektorze przedsiębiorstw są środki wewnętrzne i transfery kapitałowe. Jest to zapewne konsekwencją silnej pozycji kapitałowej niemieckich przedsiębiorstw. Przyjęty sposób postepowania badawczego nie odpowie oczywiście na pytanie o przyczyny takiego stanu rzeczy. Watro więc byłoby w dalszych badaniach dokładnie to sprawdzić. Z jednej strony sięgnąć można do kolejnych rachunków w systemie sprawozdawczości narodowej, z drugiej pokusić się można o próbę wyjaśnienia zidentyfikowanych wzorców finansowania w oparciu o wybrane teorie z obszaru finansów przedsiębiorstw, czy wręcz nadzoru korporacyjnego.

\section{Spis literatury}

CORBETT J., JENKINSON T. 1997: How is investment financed? A study of Germany, Japan, the United Kingdom and the United States, The Manchester School, Volume 65, Issue S, Supplement, Blackwell Publishers Ltd., Oxford. 
CORBETT J., JENKINSON T. 1996: The financing of industry, 1970-1989: An international comparison, Journal of the Japanese and International Economies, nr 10(1), s. 71-96.

EUROSTAT, Germany, http://ec.europa.eu/eurostat/web/sector-accounts/data/annualdata (dostęp: 30.08.2016 r.).

GUS, 1996: System rachunków narodowych (SRN). tom I, Zeszyty Metodyczne, Warszawa. GUS, 1997: System rachunków narodowych (SRN). tom II, Zeszyty Metodyczne, Warszawa.

GUS, 2000: Europejski system rachunków narodowych i regionalnych ESA 1995, Zeszyty Metodyczne i Klasyfikacje, Warszawa.

GUS, Słownik pojęć, http://stat.gov.pl/metainformacje/slownik-pojec/ (dostęp: 05.11.2016 r.).

MAYER C. 1988: New issues in corporate finance, European Economic Review, Vol. 32 (5), s. $1167-1183$.

MAYER C. 1990: Financial systems, corporate finance and economic development, [w:] R. Hubbard (ed.), Asymmetric information, corporate finance and investment, National Bureau of Economic Research, New York.

Rozporządzenie Parlamentu Europejskiego i Rady (UE) NR 549/2013 z dnia 21 maja 2013 r. w sprawie europejskiego systemu rachunków narodowych i regionalnych w Unii Europejskiej. Dziennik Urzędowy Unii Europejskiej, L 174, Tom 56, 26 czerwca 2013.

SAMBORSKI A. 2011: Wykorzystanie rachunków narodowych w analizach ekonomicznych, [w:] W. Czakon (red.), Podstawy metodologii badań w naukach o zarządzaniu, Oficyna Wolters Kluwer Business, Warszawa.

SAMBORSKI A. 2014: Znaczenie banków w finansowaniu inwestycji rzeczowych w polskim sektorze przedsiębiorstw, Zeszyty Naukowe Szkoły Głównej Gospodarstwa Wiejskiego Ekonomika i Organizacja Gospodarki Żywnościowej, nr 106, s. 21-32.

UNITED NATIONS, 2003: National Accounts: A Practical Introduction. Department of Economic and Social Affairs Statistics Division, Studies in Methods Series F, No.85, United Nations, New York.

\title{
FINANCING OF NON-FINANCIAL INVESTMENTS IN THE GERMAN CORPORATE SECTOR
}

\begin{abstract}
The article assumes two objectives, namely: to adjust the way of the research proposed by Corbett and Jenkinson to the requirements of the European System of Accounts 2010; identification of the financing structure of non-financial investments in the German corporate sector. The analysis used data from national reporting, and more specifically the two accounts included in the accumulation accounts, ie.: the capital account and financial account. It was adopted the methodology of net financing, which uses a flow of funds, and not the stocks. It was noted that, in the German corporate sector internal sources and capital transfers are the basis of non-financial investments financing.
\end{abstract}

Key words: fixed assets investment, investment financing structure 